\title{
Spatial Assessment of Water-Related Ecosystem Services to Prioritize Restoration of Forest Patches
}

\author{
Carla Cristina Cassiano*, Silvio Frosini de Barros Ferraz, Paulo Guilherme Molin, \\ Maureen Voigtlaender \& Katia Maria Paschoaletto Micchi de Barros Ferraz
}

Departamento de Ciências Florestais, Escola Superior de Agricultura "Luiz de Queiroz",

Universidade de São Paulo - USP, Piracicaba, SP, Brasil

\begin{abstract}
Forests provide several ecosystem services and its presence near streams can increase water quality and quantity. In human-dominated landscapes such as agricultural lands, the forests are usually limited to a few patches. To improve the protection of water ways in these areas, we propose a methodological framework to: (i) assess the contribution of water-related ecosystem services offered by the present forest vegetation in the landscape, and (ii) prioritize areas for recovery and restoration actions. The methodology is based on a balance between local demand (physical variables) and supply (forest characteristics) of water-related services. This balance has the advantage of showing the amount of forest that currently has potential to provide services and the areas with higher deficit of services. Although this method still needs to be validated, its simplicity and easy replicability makes our methodology a rapid assessment of forest potential to provide water-related ecosystem services within agricultural areas.
\end{abstract}

Key words: Ecosystem Services, Forest Patches, Stream Conservation, Landscape Ecology, Forest Restoration.

\section{Introduction}

Ecosystem services can be defined as the ability that nature has to supply benefits and quality of life to humankind. These benefits are distinguished into four categories: supporting, provisioning, regulating and cultural services (Millennium Ecosystem Assessment 2003). The range of ecosystem services includes food, fuel and fibers, climate regulation, spiritual and landscape benefits. Forests, in particular, can sustain many of these ecosystem services, which ultimately may lead to the conservation of water resources.

Studies from 1980 to 2005 have shown that large areas occupied by primary forests, in rainforest biomes around the world, have been converted into agricultural land (Achard et al. 2002; Gibbs et al. 2010; Hansen et al. 2010). Some parts of these areas are abandoned and can regenerate. Although the recovery and regeneration into secondary forest exhibit different characteristics from the primary forest in ecological, economic and biophysical aspects (Achard et al. 2002), its presence in the riparian area, over time, has shown improvement in physical and chemical water composition leading to the recovery of the habitat quality

\footnotetext{
${ }^{*}$ Send correspondence to: Carla Cassiano

Departamento de Ciências Florestais, Escola Superior de Agricultura "Luiz de Queiroz", Universidade de São Paulo - USP, Av. Padua Dias, 11, CEP 13418-900, Piracicaba, SP, Brasil

E-mail: cccassiano@usp.br
}

and aquatic ecosystem health maintenance (Theodoropoulos \& Iliopoulou-Geogudaki 2010).

The riparian forests have great influence over surface waters, especially in first-order streams, the effects of the vegetation range from the control of direct sunlight to the input of organic matter. The effectiveness of the riparian vegetation has been supported by many studies over the recent past (Gregory et al. 1991; Allan 2004; Studinski et al. 2012). The reforestation of riparian corridors should be one of the priority actions to improve the quality of waterbodies (Wasson et al. 2010). However, just the presence of riparian vegetation does not guarantee such environmental services; more studies are required to explain how the provision of services is affected by the forest condition and characteristics.

The objective of this study is to propose a method to assess forest patches contribution to water conservation through a balance between the local demand and the forest potential supply of services in agricultural landscapes. The demand was used to characterize a sensitivity of land erosion and its consequences; it was defined by terrain physical variables. The potential supply resulted from forest characteristics. We also aimed at assessing the percentage of forest in the landscape that, currently, has the potential to provide ecosystem services. This information was used to suggest areas that should be prioritized for recovery and restoration actions 


\section{Material and Methods}

\section{Case study - "Corumbataí" catchment}

The study area was the Corumbataí river basin, located between the latitudes $22^{\circ} 04^{\prime} 46^{\prime \prime} \mathrm{S}$ and $22^{\circ} 41^{\prime} 28^{\prime \prime} \mathrm{S}$, and longitudes $47^{\circ} 26^{\prime} 23^{\prime \prime} \mathrm{W}$ and $47^{\circ} 56^{\prime} 15^{\prime \prime} \mathrm{W}$, within São Paulo state, in the Southeastern region of Brazil. The Corumbataí catchment covers eight municipal districts, with an area of approximately $1700 \mathrm{~km}^{2}$. The region mean annual rainfall is $1367 \mathrm{~mm}$ and is characterized by a humid subtropical climate (Köppen). The pattern of deforestation in the Corumbataí catchment followed the pattern observed in the state of São Paulo, which is characterized by high rates of deforestation in the recent past. In general, the forest cover in the state of São Paulo was reduced from $80 \%$ in 1850 to $11 \%$ in 2009 (Ribeiro et al. 2009) owing to the agricultural expansion. The colonization in the region started at the end of the 18th Century and resulted in the expansion of pasture, and continued with the cultivation of coffee in the 19th Century. In the late $19^{\text {th }}$ Century, sugar cane was established, and has been expanding significantly in the $20^{\text {th }}$ and $21^{\text {st }}$ Centuries due to the increase in the biofuels demand world-wide. This widespread land occupation reduced the forest cover significantly. Currently, scattered and isolated fragments in the landscape represent forested areas in the state of São Paulo.

The proposed method was applied in quadrants of 100 $\times 100 \mathrm{~m}$, located in six square sampling units of $16 \mathrm{~km}^{2}$ previously selected in the Corumbataí catchment landscape (see Additional Supporting Information).

\section{Datasets}

Digital maps of elevation, slope and hydrography were derived from topographic maps, at the 1:10,000 scale, from the Cartography and Geographic Institute of the State of Sao Paulo (IGC). A soil map was vectorized from original mappings done by the Agronomic Institute of Campinas (IAC) from 1979 to 1989 , at the 1:100,000 scale. These maps were projected in UTM 23S (SAD 69) and manipulated using ArcGIS 9.3.

We classified historical land-use for the years of 1962, 1978, 1995, 2000, and 2008 using available images of the area. Aerial photographs were used for the years 1962, 1978, 1995, and 2000 and high resolution satellite images for 2008 . We use the method of nearest neighbor resampling to georeference images, assuming an acceptable error of $15 \mathrm{~m}$, and using a mosaic of orthorectified aerial photographs of the year 2000 as reference and cartographic database from IGC, at 1:10,000 scale. The thematic maps were produced through visual interpretation using 12 classes of land-use, being the major ones: sugar cane, pasture, forest, and secondary growth (initial). In addition, a map of the age of the forest fragments was derived from the five land-use maps. This map was a result of polygon overlap of "forest" land-use, being delimited by the polygon in the latest map (land-use map of 2008). This overlapping subdivided the patches into several polygons, allowing the classification of each new polygon into a minimum age according to their presence in each of the land-use maps.

\section{Local demand}

The local demand represents the minimum requirements of water-related services for the area. The calculation of the demand considers some local variables: the average slope, the soil texture, and the distance from the stream. Areas with higher slopes are more susceptible to soil erosion when compared to flat regions. Several studies report the importance of forest in fragile areas, such as riparian zones (Gregory et al. 1991; Allan 2004; Studinski et al. 2012). The presence of forest cover in such areas reduce risk of erosion and prevent landslides, stabilizing banks and preventing river siltation, owing to the forest deep and strong root system which promotes greater soil and water conservation compared to pasture and crops (FAO 2008).

The criteria that we used for the calculation of demand are described in Table 1. For each quadrant an average slope was extracted from the slope map, an average stream distance from the Euclidean distance from the stream mapping, and the soil texture was extracted from the soil map database (see Additional Supporting Information). Each criterion receives a score and the sum of these values establishes the demand (Figure 1b).

\section{Potential services supply}

The classification of potential forest ecosystem services supply in the study considered three criteria: the prevailing environment land-use, the average age of the forest patch, and the forest patch area. Fragmentation of diverse landscapes has resulted in the presence of many small forest patches (Tabarelli et al. 2010). The smaller the forest patch, the greater the effect of external factors (Saunders et al. 1991), such

Table 1. Criteria and scores used to quantify the demand of services for the quadrants based on slope, soil texture and proximity to the stream maps.

\begin{tabular}{ccc}
\hline Criteria & $\begin{array}{c}\text { Classes } \\
\text { description }\end{array}$ & Score \\
\hline Slope (\%) & $0-8$ & 1 \\
& $8-20$ & 2 \\
& $>20$ & 3 \\
Soil Texture & Clay & 1 \\
& Medium & 2 \\
Stream Distance $(\mathrm{m})$ & Sandy & 3 \\
& $>100$ and $>30$ & 1 \\
& $\leq 30$ & 3 \\
\hline
\end{tabular}


as the edge effect, resulting in the reduction of structural complexity (Tabarelli et al. 2010) and its ability to conserve species richness (DeFries et al. 2005). Increased aquatic biodiversity is desirable for enabling the performance of more ecological functions, assisting certain ecosystems to become more stable (Palmer et al. 1997) remaining in the landscape. Therefore, it is expected that larger, continuous and older forest patches have the ability to provide more ecosystem services. For example, increase infiltration capacity
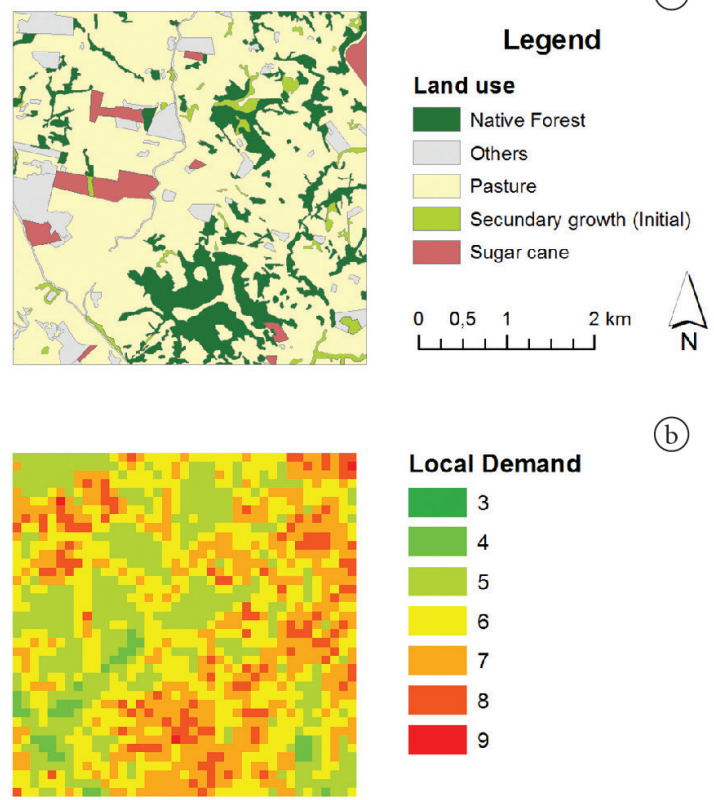

\section{Local Demand}
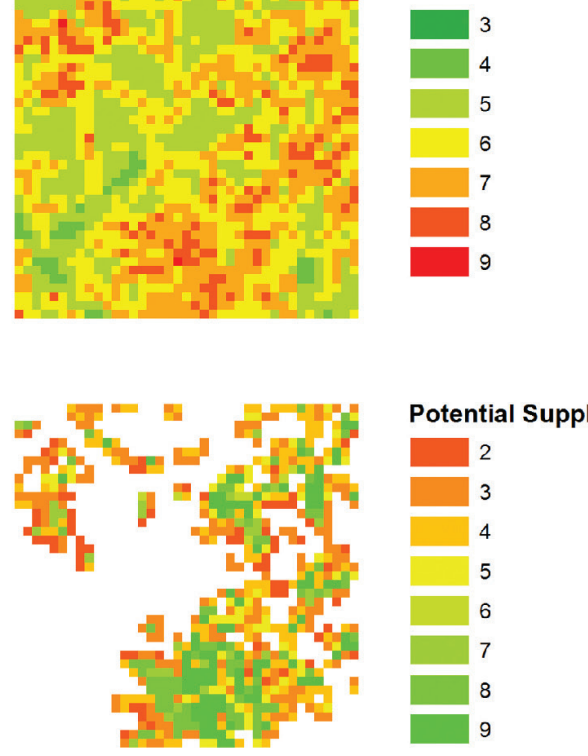

\section{Potential Supply}
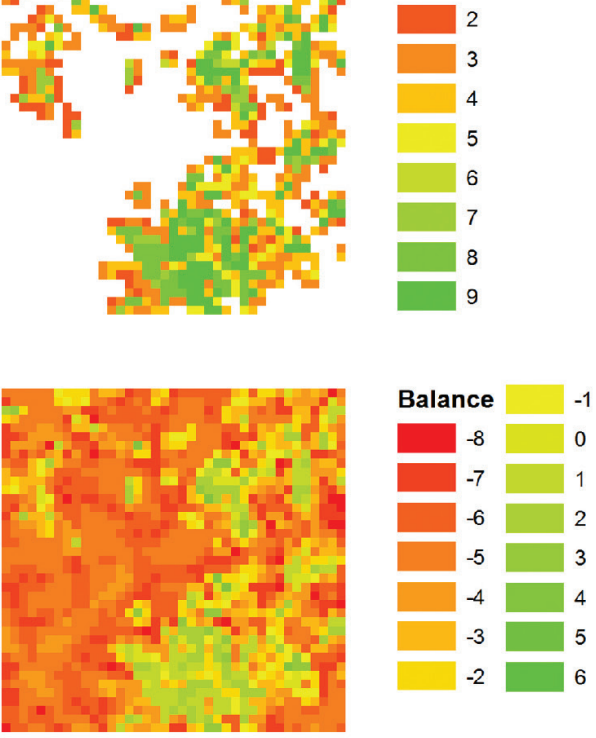

Figure 1. Balance between supply and demand of water-related ecosystem services for each quadrant. a) Land-use map of 2008. b) Local demand of service. c) Potential service supply. d) Balance of demand and supply for each quadrant. of the rainwater in the ground, because the leaf litter and the roots promote groundwater recharge, reducing runoff (Balbinot et al. 2008). Roots, worms, and insects make soil more airy, facilitating water infiltration, promoting water storage, reducing flood peaks and increasing base flow (Brauman et al. 2007). Larger fragments have, thus, higher potential to regulate river flow through the year (Calder 2002).

The criteria used for the calculation of potential supply are described in Table 2. For each quadrant, predominant neighboring land-use was extracted along with forest cover of the 2008 land-use map and the mean age from the forest age map (see Additional Supporting Information); each one received a score and the sum of these values resulted in the potential service supply (Figure 1c).

\section{Balance}

The balance was calculated by the difference between values of potential supply and local demand for each quadrant (Balance $=$ Supply - Demand). Negative values represent areas where potential for services is lower than the local demand of services, characterizing a deficit in the provision of these services. Positive values represent areas where there are surplus, and the forest has the potential to fulfill the provision of services related to water conservation.

\section{Results}

Local demand was calculated through the sum of the values of each criterion of demand (Figure 1b) and potential supply by the sum of criteria of supply (Figure 1c). The landscape balance is presented in Table 3 . The balance varies from -8 to 6 (Figure $1 \mathrm{~d}$ ). The assessment showed that $58.30 \%$ of the quadrants in the landscape did not have forest cover presenting negative values in the balance. The balance for the forest quadrants $(41.70 \%)$ present negative values for almost of them (57\%), 9\% presented the same values for

Table 2. Criteria and scores used to classify the potential services supply by existing forests in each quadrant related to water conservancy.

\begin{tabular}{ccc}
\hline Criteria & $\begin{array}{c}\text { Classes } \\
\text { description }\end{array}$ & Score \\
\hline Predominant & $\begin{array}{c}\text { Others } \\
\text { Secondary growth } \\
\text { (initial) }\end{array}$ & 0 \\
Neighborhood & Forest & 3 \\
& $\leq 3$ & 1 \\
Forest Age (years) & $3-16$ & 2 \\
& $>16$ & 3 \\
& $\leq 10$ & 0 \\
Forest Area (\%) & $10-30$ & 1 \\
& $30-60$ & 2 \\
& $60-100$ & 3 \\
\hline
\end{tabular}


Table 3. Landscape balance between the potential supply and the local demand of water-related ecosystem services provided by the forest patches. A) Distribution of Local Demand between forest and no forest quadrants. B) Balance for the forest quadrants.

\begin{tabular}{|c|c|c|c|c|c|c|c|c|c|}
\hline \multicolumn{10}{|c|}{ A) Local demand distribution. } \\
\hline \multicolumn{2}{|c|}{ Local Demand } & \multicolumn{4}{|c|}{ No forest quadrants } & \multicolumn{4}{|c|}{ Forest Quadrants } \\
\hline & & \multicolumn{8}{|c|}{$\%$} \\
\hline \multicolumn{2}{|c|}{3} & \multicolumn{4}{|c|}{10.53} & \multicolumn{4}{|c|}{1.37} \\
\hline \multicolumn{2}{|c|}{4} & \multicolumn{4}{|c|}{10.60} & \multicolumn{4}{|c|}{4.70} \\
\hline \multicolumn{2}{|c|}{5} & \multicolumn{4}{|c|}{20.99} & \multicolumn{4}{|c|}{12.01} \\
\hline \multicolumn{2}{|c|}{6} & \multicolumn{4}{|c|}{10.74} & \multicolumn{4}{|c|}{10.69} \\
\hline \multicolumn{2}{|c|}{7} & \multicolumn{4}{|c|}{4.56} & \multicolumn{4}{|c|}{9.42} \\
\hline \multicolumn{2}{|c|}{8} & \multicolumn{4}{|c|}{0.88} & \multicolumn{4}{|c|}{3.43} \\
\hline \multicolumn{2}{|c|}{9} & \multicolumn{4}{|c|}{0.00} & \multicolumn{4}{|c|}{0.08} \\
\hline \multicolumn{2}{|c|}{ Total } & \multicolumn{3}{|c|}{58.30} & & \multicolumn{4}{|c|}{41.70 (3806 quadrants) } \\
\hline \multicolumn{10}{|c|}{ B) Forest Quadrants Balance (3806 quadrants). } \\
\hline \multirow{3}{*}{$\begin{array}{c}\text { Local } \\
\text { Demand }\end{array}$} & \multicolumn{9}{|c|}{ Potential Supply of Services } \\
\hline & 2 & 3 & 4 & 5 & 6 & 7 & 8 & 9 & Total \\
\hline & \multicolumn{9}{|c|}{$\%$} \\
\hline 3 & 0.71 & 0.84 & 0.39 & 0.21 & 0.08 & 0.47 & 0.05 & 0.53 & 34.08 \\
\hline 4 & 1.92 & 2.94 & 2.52 & 0.55 & 0.29 & 1.97 & 0.89 & 0.18 & \\
\hline 5 & 3.57 & 7.36 & 5.65 & 2.10 & 0.79 & 3.68 & 3.26 & 2.39 & \\
\hline 6 & 2.89 & 5.73 & 5.15 & 2.36 & 0.71 & 2.34 & 3.02 & 3.44 & \\
\hline 7 & 1.08 & 5.20 & 5.39 & 2.23 & 0.29 & 1.68 & 2.92 & 3.81 & \\
\hline 8 & 0.29 & 1.18 & 1.31 & 0.81 & 0.13 & 0.55 & 1.13 & 2.81 & \\
\hline 9 & 0.00 & 0.00 & 0.03 & 0.08 & 0.00 & 0.05 & 0.03 & 0.00 & \\
\hline Total & & & & 56.93 & & & & & 8.99 \\
\hline
\end{tabular}

Quadrants with negative balance / 1 Quadrants with positive balance.

the local demand and potential of service supply, and only $34 \%$ of the quadrants could overcome the local demand and exert their role in the provision of water-related services.

Approximately $18 \%$ of the total of quadrants presented local demand values bigger than 7 . These quadrants should be at the priorities for restoration actions, since $5 \%$ of them present positive values in the balance, indicating that they already have potential to offer some services. The quadrants with negative balance, the $13 \%$ remaining, has $5 \%$ without forest cover and $8 \%$ with forest cover. This suggests that the restoration of forest fragments should be done before the restoration of new forest areas.

\section{Discussion}

The balance quantification showed that less than half of the forest areas are exercising their natural role of providing hydrologic services (34\%), highlighting the need of restoration and recovery of the vegetation in this landscape. The land-use change from perennial vegetation to crop farming could change the capacity of the soil in retaining and transferring water to the groundwater (Le Maitre et al. 2007), and, therefore, making restoration appear as a good option to re-establish some of the lost services. A recent study showed several initiatives of Payment for Ecosystem Services (PES) in Latin America that focus on water provision through the increase of forest cover (Balvanera et al. 2012). However, the recovery of ecosystem services through restoration practices can be slow and incomplete (Bullock et al. 2011). We believe that if recovery actions start to target the forest patches with low potential of service provision, as shown in the balance, it can become a faster way to acquire results for the protection of water resources, and may allow the forest to reach late successional stages (Paula et al. 2013). The strategy to be adopted in the study landscape would be the restoration and recovery of forest fragments with low potential of services supply to enhance the availability of services, instead of planting new forests in areas with high demand that will promote a lower supply of services.

The classification of the forests' potential supply in the provision of water-related ecosystem services is a simple technique that can provide an initial overview of the landscape. The classification can differentiate the forest patches present in the landscape through a series of maps and images. Knowing historical land-use in human-dominated landscapes can be an important tool to develop appropriate conservation strategies (Ferraz et al. 2009). The use of forest historical variables helps to characterize the vegetation and allows the application of localization criteria for restoration actions. The method proposed here can be tested to verify if the values obtained are consistent. This verification may be accomplished through comparison with other methods of land fragility and erodibility for the demand criteria, and through a survey of forest condition and successional stage for quadrants with different potential of service supply. 
Forward it also can be optimized with the use of more criteria and an appropriating weighting of their scores. If such methodology is explored thoroughly, as well as tested with data of other areas, it may become a useful practice in detecting preferential areas for restoration and conservation in the landscape.

\section{Acknowledgements}

We thank São Paulo Research Foundation (FAPESP n ${ }^{\circ}$ 2010/13627-3; FAPESP $n^{\circ}$ 2011/19767-4; FAPESP $n^{\circ}$ 2011/06782-5) for the financial support.

\section{References}

Achard F et al., 2002. Determination of deforestation rates of the world's humid tropical forests. Science, 297:999-1002. http://dx.doi.org/10.1126/science.1070656

Allan JD, 2004. Landscapes and riverscapes: the influence of land use on stream ecosystem. Annual Review of Ecology, Evolution, and Systematics, 35:257-284. http://dx.doi. org/10.1146/annurev.ecolsys.35.120202.110122

Balbinot R et al., 2008. O papel da floresta no ciclo hidrológico em bacias hidrográficas. Ambiência, 4:131-149.

Balvanera P et al., 2012. Ecosystem services research in Latin America: The state of the art. Ecosystem Services, 2:56-70. http://dx.doi.org/10.1016/j.ecoser.2012.09.006

Brauman KA et al., 2007. The nature and value of ecosystem services: an overview highlighting hydrologic services. Annual Review of Environment and Resources, 32:67-98. http://dx.doi.org/10.1146/annurev.energy.32.031306.102758

Bullock JM et al., 2011. Restoration of ecosystem services and biodiversity: conflicts and opportunities. Trends in Ecology and Evolution, 26:541-549. http://dx.doi.org/10.1016/j. tree.2011.06.011

Calder IR, 2002. Forest and hydrological services: reconciling public and science perceptions. Land Use and Water Resource Research, 2:2.1-2.12.

DeFries $\mathrm{R}$ et al., 2005. Increasing isolation of protect areas in tropical forests over the past twenty years. Ecological Applications, 15:19-26. http://dx.doi.org/10.1890/03-5258

Ferraz SFB, Vetorazzi CA \& Theobald DM, 2009. Using indicators of deforestation and land-use dynamics to support conservation strategies: a case study of central Rondônia, Brazil. Forest Ecology and Management, 257:1586-1595. http://dx.doi.org/10.1016/j.foreco.2009.01.013

Food and Agriculture Organization of the United Nations - FAO, 2008. Forests and Water: a thematic study prepared in the framework of the Global Forest Resources Assessment 2005.

Gibbs HK et al., 2010. Tropical forests were the primary sources of new agricultural land in the 1980s and 1990s. Proceedings of the National Academy of Sciences, 107:16732-16737. http://dx.doi.org/10.1073/pnas.0910275107

Gregory SV et al., 1991. An ecosystem perspective of riparian zones. BioScience, 41:540-551. http://dx.doi. org/10.2307/1311607

Hansen MC, Stehman SV \& Potapov PV, 2010. Quantification of global gross forest cover loss. Proceedings of the National Academy of Sciences, 107:8650-8655. http://dx.doi. org/10.1073/pnas.0912668107

Le Maitre DC et al., 2007. Linking ecosystem services and water resources:landscape-scale hydrology of the Little Karoo. Frontiers in Ecology and the Environment, 5:261-270. http://dx.doi. org/10.1890/1540-9295(2007)5[261:LESAWR]2.0.CO;2

Millennium Ecosystem Assessment, 2003. Ecosystems and human well-being: a framework for assessment. Washington: Island Press.

Palmer MA, Ambrose MA \& Poff NL, 1997. Ecological theory and community restoration ecology. Restoration Ecology, 5:291300. http://dx.doi.org/10.1046/j.1526-100X.1997.00543.x

Paula FR et al., 2013. Influence of forest cover on in-stream large wood in an agricultural landscape of southeastern Brazil: a multi-scale analysis. Landscape Ecology, 28:13-27. http://dx.doi.org/10.1007/s10980-012-9809-1

Ribeiro MC et al., 2009. The Brazilian Atlantic forest: how much is left, and how is the remaing forest distributed? Implications for conservation. Biological Conservation, 142:1141-1153. http://dx.doi.org/10.1016/j.biocon.2009.02.02

Saunders DA, Hobbs RJ \& Margules CR, 1991. Biological consequences of ecosystem fragmentation: a review. Conservation Biology, 5:18-32. http://dx.doi. org/10.1111/j.1523-1739.1991.tb00384.x

Studinski JM et al., 2012. The effects of riparian forest disturbance on stream temperature, sedimentation, and morphology. Hydrobiologia, 686:107-117. http://dx.doi.org/10.1007/ s10750-012-1002-7

Tabarelli M et al., 2010. Prospects for biodiversity conservation in the Atlantic forest: lessons from aging human-modified landscapes. Biological Conservation, 143:2328-2340. http:// dx.doi.org/10.1016/j.biocon.2010.02.005

Theodoropoulos C \& Ilipoulou-Georgudaki J, 2010. Response of biota to land use changes and water quality degradation in two medium-sized river basins in southwestern Greece. Ecological Indicators, 10:1231-1238. http://dx.doi. org/10.1016/j.ecolind.2010.04.010

Wasson JG et al., 2010. Large-scale relationships between basin and riparian land cover and the ecological status of European rivers. Freshwater Biology, 55:1465-1482. http:// dx.doi.org/10.1111/j.1365-2427.2010.02443.x

Received: March 2013

First Decision: May 2013 Accepted: September 2013 